\title{
Rethinking William Thomas, 'friend' of the Aborigines
}

\author{
Liz Reed
}

\section{Summary}

In this article I argue that William Thomas, who was appointed to be one of four Assistant Protectors of Aborigines in the Port Phillip Protectorate (1839-1849) has become known as 'friend' of the Aborigines of that colony largely because of having written himself into the historical record in that role. I examine the ways in which interrogations of 'whiteness' offer ways of rethinking Thomas' friendship and suggest a more complex range of attitudes and representations made by him which have contributed to enduring tropes of 'the Aborigine'.

\section{Introduction}

Assistant Protector and later 'Guardian' of Aborigines, William 'Thomas is 'known' to have been a friend of Victorian Aborigines. Thomas was one of four Assistant Protectors appointed to the Port Phillip Protectorate, 1839-1849, with George Augustus Robinson as Chief Protector. Following the disbandment of the Protectorate, he was retained as Guardian of the Aborigines, and was appointed as official visitor to all the reserves and depots established by the Board of Protection after 1860, remaining in this position until his death in 1867. Thus Thomas spent a considerable portion of his life being the friend or 'Good Father' of the Aborigines, as they purportedly called him. ${ }^{1}$ We 'know' this because Thomas in his writings told us so, over and over, thereby creating a 'memory' of himself. Following Thomas, historians have utilised the extensive primary sources he created ${ }^{2}$ and his friendship with the Aborigines has become an uninterrogated historical 'fact'. Thus Henry Reynolds in his examination of those he

1. Bride 1969: 397. Thomas frequently wrote of his popularity with 'the natives' who 'have become much attached to me', locating this attachment as resulting from his having 'slept among them, dressed and washed their wounds, and administered medicines' (see Cannon 1982: 594-95). That is, he centred himself as the figure of virtue towards whom 'the natives' were suitably grateful.

2. Thomas' papers include journals, reports, correspondence, sermons and lectures, as well as detailed census material, drawings and maps. The majority of his papers (1834-1868) are held in the Mitchell Library, Sydney, consisting of 23 microfilm reels that are also available at the Matheson Library Music Multimedia section at Monash University, Clayton, where I have accessed them for this article. There are other assorted sources by Thomas held, for example, in the State Library of Victoria and the Public Records Office, Melbourne. 
called 'white humanitarians' noted with approval that men such as Thomas were not 'armchair critics' of 1830 s and 1840 s attitudes towards Aborigines, but had 'close personal contact with Aboriginal society' ${ }^{3}$ Such close contact was seemingly valued by William Thomas as positioning him as moral and historical authority on the Aborigines; for example an 1858 letter detailing the 'manners and customs of Aborigines' railed against supposed experts on these topics who - unlike him - 'have had little or no intercourse among them [and] have completely bewilder' $\mathrm{d}$ the world'.

The William Thomas papers offer marvellous insights into the period in which he and other colonial officials engaged with their orders from Britain, the settlers in Victoria, each other, and the Aboriginal people. His diverse writings in the forms of reports and correspondence to the Chief Protector or other officials, his census collections, and his journal entries conveyed a range of information on colonial practices of surveillance of Aborigines, but also suggested his personal attempts to learn and understand language, place names, and Aboriginal conceptions of land and land boundaries. His reports on Aboriginal geographical boundaries which were judiciously defined by Rivers, Creeks \& Mountains' suggested an appreciation of a 'universal' belonging by all 'tribes', 5 at the same time that his indication of the occupation by the "two Melbourne Tribes' of 3,684 square miles at his 'coming among them in 1838' conveyed a palimpsest reading of colonial land occupation. Along with some of the other officials of the time, he was a strong advocate of Aborigines being able to testify in court. His interest in what he understood to be Aboriginal land boundaries also reflected a desire to make these conform to European ways of seeing the landscape. His writings on connections to land were often a part of his census-taking routine, and thus may also be regarded as a means by which he conveyed ownership of 'his' Aborigines to the Chief Protector and other colonial authorities. By traversing the land in search of Aboriginal bodies to be named and listed, Thomas also engaged in an exercise of inscribing his European presence on terra nullius.

As well, I argue that his extensive correspondence illustrates an attempt on his part, in this critically important early period of colonialism in Victoria, to 'appeal to a common whiteness [amongst the] European settlers' ${ }^{6}$ He was frequently concerned about the 'disagreeable' presence of whites in the Yarra encampment in September $1839,{ }^{7}$ and the temptations and disruptions caused to his Sabbath efforts by 'disgusting whites' who encouraged Aboriginal women to dance at a corroboree on a Sunday night. ${ }^{8}$ Such accounts suggest the desire to 'protect' whiteness, the decorum of which Thomas was concerned to maintain. I argue that, importantly, he also established and/ or nourished a number of tropes about Aborigines. These tropes have had a dynamic relationship with, and intersected with and sustained others that followed his period. Among these were the doomed race, the childlike race, the prostitute, the violent male, the drunkards, the grateful unfortunates, and the trope of the long-suffering and self-

3. Reynolds 1998: 22-26. See also Reynolds 1990: 129-131 for further sympathetic discussion of Thomas' role.

4. Thomas M/F 5883: CY3131: 22 June 1858.

5. Thomas M/F 5883: CY3105: 17 February 1864.

6. See Dyer 1997: 19.

7. Thomas: M/F 5883: CY2604: 16 September 1839.

8. Thomas: M/F 5883: CY2604: 15 December 1839. 
less white supporter. It is these tropes which I am seeking to deconstruct in my reading of his papers. My focus in this article is the 1830s and 40s, the early period of the Port Phillip Protectorate and its foundational inscribing of colonialism on the Indigenous landscape and people in Victoria. I am seeking to peel back the layers of Thomas' friendship with the Aborigines and suggest some ways that the more complex dimensions of their interactions might be read.

Thomas manifested the habit of whiteness that locates being human as being white. As Richard Dyer has reminded us, such an equation 'secures a position of power', ${ }^{9}$ which was something that Thomas did not question. Indeed, throughout his writings the normality of whiteness was central to his perceived right (and appointed duty) to name, categorise, watch over and record, extend or withdraw approval, and represent Aborigines as always childlike but also variously savage or docile and capable of 'civilisation'. Thus, following Dyer, I am suggesting that Thomas was unaware of his own 'raced' identity and how this gave him the power to construct and represent the world in whiteness' image. Given the 'enormous variations' in white power, humanitarianism such as Thomas' was not a contradictory impulse, but a manifestation of how white power 'reproduces itself regardless of intention ... overwhelmingly because it is not seen as whiteness, but as normal' ${ }^{10} \mathrm{I}$ will argue that Thomas was indeed a 'friend', in the context of his official role and his manner of carrying out his duties. However, in important ways he framed not only the contemporary discourses of race relations but provided the parameters within which ongoing responses to Aborigines would be shaped and resonate in the present.

I begin by examining the contours of the friendship between Thomas and his 'subjects'. I then draw on critiques of the power of whiteness offered by, for example, bell hooks, Homi Bhabha and Aileen Moreton-Robinson, to suggest ways in which Thomas' interactions with Aborigines provided crucially important foundations of surveillance and control. Although refined and reshaped, these continue to frame governmental and media discourses, as well as articulations and actions of non-Indigenous supporters. Insofar as Aborigines in colonial Victoria responded to and thereby also negotiated the friendship of which Thomas boasted, which I believe is what he did, they used it and Thomas for their own subaltern purposes.

Thus I locate Thomas' friendship as a manifestation of what Bhabha has suggested as the 'pleasurable' effect of colonial surveillance, what he describes as the very 'pleasure in 'seeing". ${ }^{11}$ As Bhabha indicates, such pleasure is dependent on 'the active consent which is real or mythical ... (but always real as myth) ${ }^{12}$ of the object of its desire, in this case, the Aborigines whom Thomas would 'protect' and be the friend of. I argue that as players in the mid-1830s humanitarian movement that prompted the British Colonial Office's establishment of the Port Phillip Protectorate as the 'solution' to its colonising errors, Thomas and his peers fetishised Aboriginal men and woman and made them hostages to their own fears, desires, fantasies and vanities. Most damagingly Thomas et al made Aborigines the site of their contestations concerning who had the greater

\footnotetext{
9. Dyer 1997: 9.

10. Dyer 1997: 9-10.

11. Bhabha 1994: 76 .

12. Bhabha 1994: 76 (his emphasis).
} 
knowledge, authority, understanding and friendship in relation to 'their' Aborigines (as they frequently referred to those under their spatial control within the districts to which they had been allocated to perform their 'protective' duties). ${ }^{13}$

My own subject position as a white female beneficiary of colonialism, as well as within the academy where I remain in a privileged position of 'knower', 14 is one of the imperatives behind my attempt to suggest a counter-reading of Thomas' papers in order to loosen the constraints of binary readings of 'good' and 'bad', 'friend' or 'foe' in colonial relationships. I am concerned with the continued tendency of white historians and others to uncritically identify historical actors such as Thomas as 'good whites' in post 1788 history. Perhaps this is largely because recently contested meanings of Australia's 'past' appear to have been waged with unspoken agreement by both 'sides' that these are questions of white academic ownership. The absence of Indigenous people, largely, from the public debates that have been held between Windschuttle and his opponents is arguably a response to the perception that this is really about white men arguing with each other. Such an observation was made by Aileen Moreton-Robinson during a session of the 'Melbourne Conversations at Fed Square' in June 2003, and on the same occasion another Indigenous academic reported that at that time no Indigenous historians had been invited to participate on panels debating Windschuttle. With everything else in the historical record bitterly fought over, the privilege of whiteness in Australia has remained unexamined and unscathed, and as John Maynard has observed, 'the whole thing has degenerated into an exercise of political and intellectual point-scoring with little thought or compassion for the Aboriginal suffering in the past, or for the scars of that horrific impact that remain deeply embedded in the Aboriginal psyche'. 15

\section{Some observations about the Protectorate and Protectors}

Whatever else may be said about the Assistant Protectors, they were well provided for by the state, being paid 250 pounds per annum plus rations that were higher than the going rate around Melbourne. ${ }^{16}$ This did not prevent a sustained and varied range of complaints about pay and conditions, about which they were able to demonstrate an otherwise rare unity.

Vivienne Rae-Ellis in her study of Chief Protector George Augustus Robinson observed that 'as a group ... [the six Protectors] presented few admirable qualities and a collection of flaws large enough to arouse the suspicions of the most generous observer'. ${ }^{17}$ The better educated and well-connected Thomas was not averse to pulling class-based rank on Robinson whose self-consciousness about his lower class status and mannerisms was exacerbated by the intense rivalry between them. Their initial solidarity in the face of settler opposition to the presence of the Protectorate was soon

13. Thomas' writings frequently contained phrases such as 'I had not seen some of my blacks for three months', or designated more specific notions of his special relationship, eg 'on this day many of my Blacks and the Goulbourne tribe ...', see Thomas: M/F5883: CY3131, 22 June 1858.

14. Moreton-Robinson 1999: 30.

15. Maynard 2003: 144 .

16. Cannon 1982: 453.

17. Rae-Ellis 1988: 192. 
overcome by their contest over who possessed the greater understanding of the Aborigines, ${ }^{18}$ expressive of the contestation over Aboriginal bodies that has remained a constant in 'race relations' in this country.

Rae-Ellis argued that although some of the Protectors 'cared for and grew to love the Aborigines, each one, with the exception of Thomas, put his own interests first and the interests of the tribes last ${ }^{19}$ Her comparative sympathy for Thomas may arise from the selflessness she saw in the evidence left behind by him - his 'fatal mistake' of telling the truth about the manifest failure of his attempts to 'protect' the Aborigines. ${ }^{20}$ Certainly Thomas did not resile from frequently supplying those in authority over him with tales of uncontrolled drunkenness and vice on the part of the Aborigines and his inability to prevent or control such behaviour. This genuine concern about a compelling problem reflected Thomas' doubtless humane attitude but also served as a device by which he 'centred' himself in the narrative and the meanings and processes of 'protection'. Moreover, Thomas' depiction of Aborigines' behaviour when intoxicated as 'so outrageous ... [that] they are more like maniacs' ${ }^{21}$ foregrounded Aborigines as deviant and uncivilised, resonating with present day discourses of 'problem' drinking which locates such behaviour as particularly Indigenous. The main concern Thomas appeared to wish to convey in this communication was that his attempts to intervene on such occasions prompted him to 'hold my life upon a very slender thread' ${ }^{22}$ His request for police to be ordered to watch the house of the apparent supplier of liquor was seemingly secondary to his desire to foreground threats to his personal safety in such circumstances.

Thomas' frequent admissions of his failure to prevent such regular 'lapses' and what these represented within white society - as well as possibly revealing a naïve honesty - may also be seen as providing the opportunity for him to represent himself as the bearer of a more difficult task than the other Protectors with whom his ego was in competition. Silence on their part may have enabled Thomas and others to believe that only he took his responsibilities seriously and was an honourable if foolish man who was prepared to admit his shortcomings. Indeed within the more private space provided by his journal, Thomas was inclined to locate his absence of success within the orders he was given, suggestive of a desire to provide his own absolution in the personal observations thus provided. 'Orders are orders and must be obeyed ${ }^{\prime 23}$ he wrote in response to what he perceived as an unreasonable instruction to proceed to Mount Macedon to deal with 'disturbances'. It is unclear from this journal entry as to whether his frustration with 'orders' arose from the lateness in the day on which he received them, the fact that he was to proceed 'alone without any weapon' or because as he observed with more reason, 'What in the world can Government think a man can do alone, unknown to the Blacks'. ${ }^{24}$ Indeed, blame was more ubiquitous. Thomas responded to a 'truly appalling' scene of sickness where he and other Protectors were

18. Rae-Ellis 1988: 183.

19. Rae-Ellis 1988: 192.

20. Rae-Ellis 1988: 184 .

21. Thomas M/F 5883: CY2946, 9 November 1839.

22. Thomas M/F 5883; CY2946, 9 November 1839.

23. Thomas M/F 5883: CY2604, 19 July 1839.

24. Thomas M/F 5883: CY2604: 19 July 1839. 
unable to provide even a blanket, by suggesting that 'Could the British Parliament or His Excellency have felt our feelings, they could certainly never have placed us in such a position without means. ${ }^{25}$ By locating responsibility or blame externally, both to himself via his journal and to the Chief Protector and others via his official reports and correspondence, Thomas was able to retain 'the high moral ground' for his fearsome honesty in admitting his failings which were really the result of the inadequacies of his superiors and the manner in which the Protectorate was organised and funded. Such explanations thus provided a further distancing from having to question his own participation within the performance of 'protection'. Being able to blame others gave him the opportunity to represent himself in ways that he clearly found admirable and comforting. At the same time, his apparent conviction of the certainty of the virtues of bringing Christianity to people he referred to as 'poor heathen[s] of this our adopted land', ${ }^{26}$ provided him with occasions for 'mournful reflection' of a most narcissistic kind. Whilst to all intents and purposes writing about those in his care, Thomas maintained his position at the centre of his reports and correspondence, situating himself as the all-knowing and caring (underpaid) Assistant Protector.

Thomas no doubt believed that his friendships with Aborigines occurred on his terms. Clearly he sought to frame such friendships according to the patterns of living and working with which he was able to persuade Aborigines to comply (or appear to comply for their own strategic purposes). Regardless of his humanitarian role and his own personal sympathies or perhaps because of these, Thomas was inevitably strongly implicated in the shifting power relationships of the late $1830 \mathrm{~s}-1840$ s in colonial Victoria. Much of what he wrote was in the way of ethnographic notes on the behaviour of Aboriginal people, his gaze upon them being characteristically framed by the normalcy of all things European. Thus for example, he recorded in his journal in November 1839 that the 'few natives here are as our family. As soon as we are up they are up and about us ... Had service with them it is astonishing what attention they pay.' ${ }^{27}$ Little did it occur to him that such occasions enabled colonists to be subjected to the ethnographic gaze of the Aborigines whereby knowledge of 'whiteness' could be gained. As bell hooks has argued, black people' have acquired a "special" knowledge of whiteness gleaned from close scrutiny of white people' in order to help them 'cope and survive in a white supremacist society'. ${ }^{28}$

\section{'Gellibrand ... called himself my brother', or 'The blacks ... were very fond of $\mathrm{me}^{\prime}$}

Thomas' journal entry for 23 March 1839 recorded his arrival on the scene after the first fight since the setting up of the Protectorate. Among the many wounded was 'Gellibrand who called himself my brother'. ${ }^{29}$ A couple of months later Thomas constructed Gellibrand as 'tame' and wrote him into history as a friend to whom he was 'fatherly'. Thomas' account (partly written in a form of pidgin English) was of Gellibrand arriving at his tent door on a cold May morning, bearing firewood, which elicited Thomas'

Thomas M/F 5883: CY2604: 19 July 1839.

Thomas M/F 5883: CY2604: 28 May 1839, my emphasis.

Thomas M/F5883: CY2604: 3 November 1839.

hooks c1992: 165 .

Thomas M/F 5883: CY2604: 23 March 1839. 
response 'good fellow, you Gellibrand'. Gellibrand's intended entry to the tent was prevented by Thomas' information that 'I said my lubra not up', at which what might be interpreted as a moment of male bonding was recorded: 'he laugh'd heartily and went out' ${ }^{30}$ Gellibrand later breakfasted with him and Mrs Thomas, both of them pressing tobacco and potatoes on him ('Mrs T. filled his pockets full of Potatoes') in response to Gellibrand's information that he was going away for five days. Their desire to make Gellibrand resemble them and conform to patterns of what Thomas termed 'going out' and return to their paternal and maternal control was fetishised in his journal. Here he observed that he and his wife had always made 'this poor fellow ... comfortable to our ways', and that 'he would show no wish to the contra'. Gellibrand had 'bent his knee with us, shaved and wash'd himself, and one Sunday evening brought 3 other blacks to our evening service'. ${ }^{31}$ Thomas interpreted such mimicry as an acceptance of 'civilised' ways, whereas an examination of these journal entries, two months apart, reveal little about Gellibrand beyond what may be interpreted as customary behaviour towards visitors to his country as well as an attempt to assimilate Thomas to Aboriginal reciprocal ways of behaving. As well, Gellibrand was incorporating Thomas as 'brother' into a formalised relationship whereby he could relate not only to him but to other kin in ways that conformed to Aboriginal custom. Thus Gellibrand can be read as the principal historical actor here; he understood Thomas to carry some of the authority of the colonisers and was seeking to utilise their relationship in order to maintain his own authority in responding to his presence.

Thomas, though, could only see it through his European eyes which centred him as the figure around which other actors (including his 'lubra') revolved. His configuration of his relationship with Gellibrand (and indeed of all the Aborigines with whom he came into contact) reflected habits of whiteness which (as hooks argues) enable white people to believe 'they are seen by black folks only as they want to appear'. ${ }^{32}$ Thus Thomas was able to imagine Gellibrand's relational responses to his presence as evidence of an evolving dependence. Its pleasurableness was heightened by frequent reminders to himself that his 'sable Brother Gellibrand ... honour[ed] us with his company at breakfast'. ${ }^{33}$ Even when a baby was named after Thomas' 'lubra Suzannah', ${ }^{34}$ he was unable to see anything beyond a desire to please him in this action.

Thomas was not alone in being 'brother' to Aboriginal men, suggesting the pervasiveness with which Aborigines sought to negotiate colonial relationships. His journal on 22 January 1839, just a few weeks after his arrival in the colony to take up his appointment presented a particularly exotic (and perhaps also homoerotic) portrayal of a 'particularly fine young man' among a number of 'fine young men' encountered on his way to Melbourne. This young man's 'majestic appearance' was enhanced by the 'clean blanket [worn] down to his legs', and his 'dignified and frank' looks as well as his well-spoken English, 'remarkable' because of its 'correct pronunciation'. Particularly striking, though, was the softness of this young man's speech, which was 'in fact more

30. Thomas M/F 5883: CY2604: 3 May 1839.
31. Thomas M/F 5883: CY2604: 3 May 1839.
32. hooks c1992: 169.
33. Thomas M/F 5883: 2604: 1 May 1839.
34. Thomas M/F 5883: 2604: 7 November 1839. 
like that of a female 35 - clearly a memorable early meeting, during which Captain Lonsdale was identified by the young (nameless) man as 'his brother'. ${ }^{36}$

Similarly Assistant Protector James Dredge in March 1839 identified 'a fine athletic [Bonurong] man ... who calls himself my brother and names himself 'Mitter Dredge $^{\prime \prime}$ as one of the wounded in 'a commotion amongst the blacks' which was only alleviated by his 'presence amongst them ... all day'. ${ }^{37}$ The mimicry involved in taking identities such as 'Mitter Dredge' was entirely missed in the desire of these white men to promote themselves as possessing the necessary traits of character to be able to deal with the Aborigines.

\section{White fantasy tropes in Thomas' writings}

One of Thomas' major fears revolved around his inability to control the behaviour of Aborigines and whites in relation to alcohol. His representation of this 'problem' in his writings was arguably a significant contribution to attitudes forming among officialdom and colonial society and framed the alcohol trope which, as Marcia Langton has suggested, continues to absorb white Australians in public discourse, and has provided a device by which a national ignoring of the 'real problems associated with misuse of alcohol'38 has been achieved. As Langton has noted, 'the image of the "drunken Aborigine" ... predated the ready availability of alcohol to Aboriginal people' ${ }^{39}$ Indeed, the illicit supply of alcohol was one of William Thomas' chief concerns about which he unsuccessfully sought police intervention. Whilst the genuine depths of Thomas' concern are clear, the fact that unworthy white men were involved in the traffic of alcohol for a variety of pecuniary and sexual motivations can be seen as threatening to the social world that he sought to create in which his control of dependent Aborigines was secure. I argue that there was more at work in white humanitarians' almost obsessive concern about alcohol and Aborigines - that the principal focus was really on the 'bad' whites who supplied the alcohol. As Richard Dyer has reminded us, 'bad' behaviour on the part of white people signifies 'failing to be "white". 40 Those Aborigines who consumed alcohol, and behaved 'like maniacs ${ }^{\prime 1}$ on the other hand, were fulfilling the stereotype-in-the-making of the 'drunken Aborigine'. So embedded was this trope by 1839 that the absence of any 'drunken cases' was noteworthy for inclusion in Thomas' journal on 25 November, ${ }^{42}$ indicative of how (as Dyer has argued) when a 'black person ... is good', this is experienced by whiteness as 'a surprise', 43 given the power of black/ white morality that is racially located within discourses of whiteness.

The doomed race trope was already in 'the colonial imagination' by the 1820 s. Thomas appears to have joined other colonial observers in what Russell McGregor has identified as the 'irresistibly attractive ... notion of inevitable Aboriginal extinction' ${ }^{44}$

\footnotetext{
35. Thomas M/F 5883: CY2604: 22 January 1839.

36. Thomas M/F 5883: CY2604: 22 January 1839.

37. Cannon 1982: 449.

38. Langton 1993: 196.

39. Langton 1993: 196.

40. Dyer 1997: 63 .

41. Thomas M/F 5883: CY2946: 9 Nov. 1939.

42. Thomas M/F 5883: CY2604: 25 November 1839.

43. Dyer 1997: 63 .
} 
Whereas from the comfort of the Colonial Office in London James Stephen was able to make more insightful observations about the only real solution to colonisation being to 'teach[ing] [Aborigines] the art of war and supplying them with weapons and munitions - an act of suicidal generosity which of course can never be practised', 45 Thomas and his peers - on the ground in Victoria - were inclined to centre themselves in their discussions of the 'doomed' Aborigines. That they were presiding over the inevitability of the demise of the Aborigines was not something they questioned; rather, they seemed intent on writing themselves into its historical record.

In a lengthy and wide-ranging report to Chief Protector Robinson early in 1840 Thomas articulated a number of the tropes investigated here, as well as continuing his just advocacy for the admission of Aboriginal evidence in legal cases. This report provided an amazing mish-mash of positive and negative views and representations of 'savages' who 'live in the greatest harmony among themselves', 6 and firmly located Thomas as the ethnographic expert, concerned among other things about the 'inevitable crisis $^{47}$ of extinction. The imposition of European patterns of existence were touted by Thomas as a 'half way [meeting with] their erratic habits', such as encouraging Aboriginal men to 'occasionally pursue' hunting. To this end he proposed the establishment of an asylum - under his control - that would achieve the trinity of 'shelter' for the 'infirm', the civilising benefits of education for the young and employment for the 'industrious'. Such an establishment would, Thomas added, leave the Aborigines 'without an excuse' and 'as a nation the British character exonerated' ${ }^{48}$

Linked to the trope of the doomed race was that of the childlike race, fond of Thomas and selected other whites. Aborigines viewed as children marked absence: not civilised, not Christian, not settled and industrious. Positive childlike attributes were what Europeans encouraged as dependence and affection for kind people like Thomas. Thomas' recording of Aborigines in the Arthur's Seat area being 'delighted at my coming down, more so as I told them I was going to live among them', 99 legitimated both his own presence as well as European occupation of Aboriginal lands as a matter of natural progression. Indeed the entire Thomas family was welcomed by 'lubras and children' upon their arrival at Tubberrubabel, ${ }^{50}$ another indication of attempts to incorporate them into Aboriginal patterns of occupation. The obvious affection of many Aborigines for Mrs Thomas, particularly on the part of some of the women, was a matter of pride for Thomas, not the least because of the insulting behaviour towards her on the part of Robinson from time to time. ${ }^{51}$ That such affection may

44. McGregor 1997: 14.

45. Cannon 1982: 757.

46. Thomas M/F 5883: CY3802: 29 February 1840.

47. Thomas M/F 5883: CY3802: 29 February 1840.

48. Thomas M/F 5883: CY3802: 29 February 1840.

49. Thomas M/F 5883: CY2604: 17 August 1839.

50. Thomas M/F 5883: CY2604: 12 October 1839.

51. For example, Robinson's criticism of Mrs Thomas' attention to an Aboriginal child, which seems to have been a part of a more widespread period of disagreement between Thomas and the Chief Protector, see for example Thomas M/F 5883: CY2604: 14 August and 8 November 1839. (The complex relationships between Aboriginal women and white women throughout the nineteenth century is a question too large to embark on here, but is the focus of another research project which I am conducting.) 
also have carried the potential for a gendered negotiation between these women was characteristically missed by him. Instead, Mrs Thomas's virtues were displaced onto her husband, with Thomas congratulating himself in his journal for 'the blessings of a good wife ${ }^{52}$

Perhaps the most explicit linking of the perceived inherent childlike character of Aborigines and their acceptance of the white presence among them was Thomas' observation in the lengthy report to Robinson in late 1839, that 'when they attach themselves to a white person their affection knows no bounds', in spite of their more 'savage' inclination (as he (mis) understood it) to 'soon forget their dead' ${ }^{53}$ In this telling passage, it was the presence of whites/ness amongst the Aborigines of the Westernport district that was privileged. Their 'boundless affection' for whites might thus be interpreted, I argue, as a device that encouraged colonial officials such as Thomas to believe that their presence had become accepted as normal by the Aborigines. So determined was Thomas to inscribe this 'affection' upon colonial relationships that his census of births and deaths among the Westernport Aborigines that accompanied his report to Robinson, included in its 'remarks' column the note that a Bunurong man named Kurnboro, aged 41 and married was 'much attached to whites'.54

Like children, though, Aborigines were also described by Thomas as 'impatient, greedy folks', ${ }^{55}$ when waiting for food to be provided by him, who were also devious, feigning illness in order to obtain government provisons. ${ }^{56}$ Thomas apparently saw no contradictions in such observations, in spite of the extent and manner in which the provision (or otherwise) of food represented power and control for the colonisers.

Intersecting the childlike and doomed race tropes was the prostitution of Aboriginal women by 'their' men, perhaps the most enduring, insulting and damaging stereotype. Not only did this continuing European construct of Aboriginal gender relations facilitate oppressive state practices such as the removal of Aboriginal children from their families and the gendered focus of the policy of assimilation ${ }^{57}$ but it has been perpetuated in the 'history wars' by Keith Windschuttle ${ }^{58}$ as well as by 'sympathetic' white academics. Although increasingly contested, for example by Tracey Moffatt's film Nice coloured girls and Shayne Breen's response to Windschuttle in Whitewash, ${ }^{59}$ the trope of prostitution arguably owes much to early writers such as Thomas. His lengthy report on Westernport Aborigines in 1840 praised their fondness as parents, describing 'many' of them as 'as constant and domesticated in their way, as in civil society'. He tempered these positive attributes that apparently placed them in some alignment with 'civilisation', with a reminder that 'debauchery and exchange of wives' was also common. ${ }^{60}$ His accounts of 'prostitution' frequently placed him at their centre, as the

52. Thomas M/F 5883: CY2604: 10 December 1839.

53. Cannon 1982: 624

54. Cannon 1982: 626

55. Thomas M/F 5883 CY2604: 6 September 1839.

56. Thomas M/F 5883 CY2604: 24 September 1839. Another contemporary trope of 'welfare bludgers' in the making, perhaps?

57. See for example Goodall 1995: 75-99.

58. Windschuttle 2002: 384-386

59. Breen 2003: 148-50. See also letters to the editor The Age 30 August and 2 September 2003: 14.

60. Thomas M/F 5883: CY3802: August 1839-February 1840. 
saviour of individual Aboriginal women from white men who would procure them. The women were effectively peripheral to his account, its focus being on the blacks [who] were willing to accommodate ${ }^{\prime 61}$ such white men and upon himself as powerless to prevent this. 62

Indeed, the inability to order life around him according to his precise wishes produced one of the most extensive tropes of Thomas in this period, which I'll call 'poor me'.

As noted, all Assistant Protectors complained bitterly and frequently about the insufficiency of their salaries. Other complaints related to their unwillingness to carry out the tasks which they had known were to be theirs when appointed, particularly removing themselves and their families to 'the bush'. Some worried about the effects being 'removed from civilisation' might have on their children, 'without the smallest hope of attaining the commonest education', as well as the hardships for their wives without servants. ${ }^{63}$ So afraid was William Thomas of the sexuality of Aboriginal women and men and of their customary fighting to settle sexual matters, that he 'sent [his] daughter from the encampment for safety' in December 1839 because 'these people are lustfully as savage as ever and not to be depended on'.64

It is clear that much of Thomas' self pity was connected to his concern for 'his' Aborigines, and therefore also frequently intersected with his feelings of superiority towards and conflict with the authorities, in particular the Chief Protector. Occasionally his sympathy for himself arose from his concern for his wife who was at times poorly and rudely treated by Robinson to the extent that this made her ill. As Thomas' 'helpmeet' - and for his communications with Aborigines - his 'lubra', Mrs Thomas' presence enabled his writings to maintain their focus resolutely on himself - as he protested the treatment of her. Not that he was alone in this, James Dredge also lamented his 'dreadfully depressed ... mind' as well as his wife's suffering from ill health, and the general circumstances of life encountered in the colony, the decision to take up his Assistant Protector position clearly being perceived as a disastrous one. ${ }^{65}$

A frequent complaint of Thomas was the inadequate provision of blankets for the Aborigines, expressive of the poor planning of 'protection' by the British Colonial Office, which should 'never have ... placed [Thomas and his colleagues] in such a position without means' ${ }^{66}$ As a signifier of control and bodily inscription, blankets require further examination; for Thomas their absence provided the occasion to demonstrate the benevolence of the Protectors in giving the 'blankets from our own beds', ${ }^{67}$ thereby shifting the focus from the shivering Aborigines to the generous white men. Such accounts of individual sacrifice were frequent in Thomas' journal, one being occasioned by a description of a visit of a 'particularly attractive' widow and her three children to his tent. Thomas might have had a bit of an eye for attractive Aboriginal women who like this one - were often the recipients of 'some beads', which he did not merely give,

\footnotetext{
61. Thomas M/F 5883: CY2604: 13 November 1839.

62. Thomas M/F 5883: CY2604: 9 November 1839

63. Cannon 1982: 428.

64. Thomas M/F 5883: CY2604: 17 December 1839.

65. Cannon 1982: 428.

66. Thomas M/F 5883: CY2604: 5 May 1839.

67. Thomas M/F 5883: CY2604: 10 May 1839.
} 
but 'put [them] on'. His concern at this meeting was that he was running out of supplies, which was at odds with his mission to 'civilize, protect and see that their wants are supplied ...'. Instead, the complaint poured out to his journal was that 'One third of my income will unavoidably be spent upon these poor creatures. What influence can ever be obtained in the absence of means? ${ }^{\prime 68}$ Indeed, such 'absence' was a source of considerable misery for Thomas causing him to identify the Aborigines he offered his friendship to as 'a great tax upon me and much reduc[ing] my salary'. ${ }^{69}$ Perhaps welcoming the opportunity to question Thomas' supposedly self-sacrificing nature, Chief Protector Robinson, no doubt also frustrated by his constant complaints, observed with some perspicacity that Thomas gave charity then complained of it. ${ }^{70}$

Most often, though, Thomas' self-pity was unrelenting in its representation of the 'awful life I lead"71 which was his most favoured phrase for expressing it. Whilst the cause of much of his self-pity was the 'misbehaviour' of Aborigines and white men alike, especially organised around the tropes of drunkenness and sexual immorality to which he contributed, he also suffered because of an absence of respect and response on the part of colonial officials. His communications were 'treated with contempt' by Police Magistrates, ${ }^{72}$ the pain this caused him arguably arising as much from the failure of these white men to demonstrate the superior value of whiteness.

Thomas' final self-pitying words on his first year as 'friend' of the Aborigines were contained in a lengthy letter to Robinson in October of 1839. Enumerating the frustrations caused by the lack of cooperation from the police magistrates, following which he reiterated that the Aborigines 'have become now much attached to me', it was Thomas who was badly done by in this account. Reminding Robinson - whether consciously or not - of his class superiority over him and of his 'circle of pious esteemed friends [and] livelihood [derived from] a genteel profession patronised by the nobility and gentry', the complaint reached a crescendo of anger, as Thomas 'might have held a situation in America of 700 pounds per annum but refused it'. ${ }^{73} \mathrm{His}$ despair occasioned by these assorted slights and missed opportunities - - in spite of his assurance in the same paragraph that in choosing to 'engage in the Aboriginal cause ... It was not the mere salary that brought me here', ${ }^{74}$ became inextricably linked with his trope of the doomed race. Thus, in linking his inability to carry out his friendship with the Aborigines with what he perceived to be 'a mystical cloud of hapless bodings hanging over' them, Thomas appeared to be wishing both to suffer the same fate as 'his' Aborigines, and to provide an explanation for the culpability of other whites in this. In doing so, he was able to maintain what appears to have been a complete ignorance of his complicity in the colonial project that had brought him to Port Phillip.

68. Thomas M/F 5883: CY2604: 30August 1839.

69. Thomas M/F 5883: CY2604: 21 September 1839.

70. Thomas M/F 5883: CY2604: 8 November 1839. The fact that Thomas himself recorded this observation made by Robinson adds strength to the argument about the depth of Thomas' self-absorption with his hard life as 'friend' of the Aborigines.

71. Thomas M/F 5883: CY2604: 9 and 11 November 1839. A variation on this phrase was 'what an awful existence', see for example Thomas M/F 5883: CY2604: 22 November 1839.

72. See for example Thomas M/F 5883: CY2604: 28 November 1839.

73. Cannon 1982: 593-95.

74. Cannon 1982; 595. 


\section{Acknowledgements}

A Monash University Arts Faculty Small Grant for 2002 assisted in the research for this article and the compilation of a comprehensive Index to Thomas' papers by Dr Pauline Byrt, which has been exceptionally helpful in the writing of this article.

I would like to thank the editor and the two anonymous referees for their helpful comments on this article; thanks also to participants in the Centre for Australian Indigenous Studies research seminar series convened by Dr Jane Lydon for their comments on a version of this article presented in October 2003.

\section{References}

\section{Primary sources}

William Thomas papers 1834-1868 [microform], Microfilm 5883, CY 3131, 3105, 2604, 2946 and 3802, Matheson Library Music Multimedia, Monash University, Melbourne.

\section{Secondary sources}

Bhabha, HK 1994, The location of culture, Routledge, London.

Breen, S 2003, 'Re-inventing social evolution' in Whitewash: on Keith Windschuttle's fabrication of Aboriginal history, R Manne (ed), Black Ink Agenda, Melbourne.

Bride, TF 1969 edition, Letters from Victorian Pioneers: being a series of papers on the early occupation of the colony, the aborigines, etc., addressed by Victorian pioneers to His Excellency Charles Joseph La Trobe Esq., Lieutenant-Governor of the colony of Victoria, Robt S Brain, Government Printer for the Trustees of the Public Library, Melbourne.

Cannon, M (ed) 1982, Historical Records of Victoria, Foundation Series, Volume 2B, Aborigines and Protectors 1838-1839, Victorian Government Printing Office, Melbourne.

Dyer, R 1997, White, Routledge, London.

Goodall, H 1995, "Assimilation begins in the home': the state and Aboriginal women's work as mothers in NSW, 1900s to 1960s', Labour History 69: 75-99.

hooks, b c1992, Black looks: race and representation, South End Press, Boston.

Langton, M 1993, 'Rum, seduction and death: 'Aboriginality' and alcohol', Oceania 63: 195-205.

Maynard, J 2003, 'Australian history - lifting haze or descending fog?', Aboriginal History 27: 139-146.

McGregor, R 1997, Imagined destinies: Aboriginal Australians and the doomed race theory, 1880-1939, Melbourne University Press, Carlton.

Moreton-Robinson, A 1999, 'Unmasking whiteness: a Goori Jondal's look at some duggai business' in B McKay (ed), Unmasking whiteness: race relations and reconciliation, Queensland Studies Centre, Griffith University, Nathan, Queensland.

Rae-Ellis, V 1988, Black Robinson: Protector of Aborigines, Melbourne University Press, Carlton.

Reynolds, H 1998, This whispering in our hearts, Allen and Unwin, St Leonards.

— 1990, With the white people, Penguin Books, Ringwood.

Windschuttle, K 2002, The fabrication of Aboriginal history, Macleay Press, Sydney. 